Sains Malaysiana 50(6)(2021): 1511-1520

http://doi.org/10.17576/jsm-2021-5006-01

\title{
Soil Fauna Community Diversity and Response to Wetland Degradation in Nanniwan Wetland, Shaanxi, China
}

(Kepelbagaian Komuniti Fauna Tanah dan Respons terhadap Kemerosotan Kelembapan Tanah di Tanah Bencah Nanniwan, Shaanxi, China)

\author{
Changhai LiU*, Ying ShaO \& SiPInG CaO
}

\begin{abstract}
This study is to investigate the soil fauna community characteristics in the Nanniwan wetland, as well as their responses to changed environmental factors. Soil fauna from six representative habitats in the Nanniwan wetland were studied, in the spring, summer, autumn, and winter of 2016. Soil fauna community composition, density, and distribution were investigated. The relationships between soil fauna distribution and soil physicochemical properties were also analyzed. Overall, 3285 individuals were harvested, which belonged to 4 phyla, 10 classes, and 26 orders. The soil fauna density and group numbers differed among these habitats. The structure of the reclaimed wetland soil fauna community was the simplest among all these habitats. Wetland reclamation and degradation reduced the density and diversity of soil fauna, and changed the functional groups of soil fauna, resulting in decreased saprozoic soil fauna and increased predacity soil fauna. The total organic carbon content and the soil pH value represented the main influencing factors of soil fauna distribution. The soil fauna density was positively correlated with the soil total organic carbon and total nitrogen contents, while the soil fauna density was negatively correlated with the $\mathrm{pH}$ value. The soil fauna density is closely associated with the environmental factors in the Nanniwan wetland. These findings would help to quantitatively predict and evaluate the ecological function of soil fauna in the Nanniwan wetland.
\end{abstract}

Keywords: Diversity characteristics; environmental factors; Nanniwan wetland; soil fauna; wetland degradation

\section{ABSTRAK}

Kajian ini adalah untuk mengkaji ciri komuniti fauna tanah di tanah bencah Nanniwan, serta tindak balas mereka terhadap faktor persekitaran yang berubah. Fauna tanah daripada enam habitat mewakilkan tanah bencah Nanniwan dikaji pada musim bunga, musim panas, musim gugur dan musim sejuk tahun 2016. Komposisi, kepadatan dan penyebaran komuniti fauna tanah dikaji. Hubungan antara taburan fauna tanah dan sifat fizikokimia tanah juga dianalisis. Secara keseluruhan, 3285 individu telah dituai yang tergolong dalam 4 filum, 10 kelas dan 26 order. Kepadatan fauna tanah dan bilangan kumpulan adalah berbeza antara habitat ini. Struktur komuniti fauna tanah di tanah bencah yang diambil semula adalah yang paling sederhana antara semua habitat ini. Penambakan dan degradasi tanah bencah mengurangkan kepadatan dan kepelbagaian fauna tanah serta mengubah kumpulan fauna tanah yang berfungsi, mengakibatkan penurunan fauna tanah saprozoik dan peningkatan fauna tanah. Keseluruhan kandungan karbon organik dan nilai pH tanah mewakili faktor utama penyebaran fauna tanah. Kepadatan fauna tanah berkorelasi positif dengan jumlah karbon organik tanah dan kandungan nitrogen, manakala kepadatan fauna tanah berkorelasi negatif dengan nilai $\mathrm{pH}$. Ketumpatan fauna tanah berkait rapat dengan faktor persekitaran di tanah bencah Nanniwan. Penemuan ini akan membantu untuk meramal serta menilai fungsi ekologi fauna tanah di tanah bencah Nanniwan.

Kata kunci: Degradasi tanah bencah; faktor persekitaran; fauna tanah; kepelbagaian ciri; tanah bencah Nanniwan

\section{INTRODUCTION}

Wetland is a transitional ecosystem between land and water, with abundant biodiversity, which plays an important role in agricultural production, regional climate improvement, and global ecological balance maintenance (Whiles \& Goldowitz 2001). As important component of wetland ecosystem, soil fauna in wetland not only provide one of the important food sources for wetland waterfowls, but also actively participate in the material circulation and energy flow of the terrestrial ecosystems (Camplin et al. 2016; Jiang et al. 2016). Wetland soil fauna strongly influence the decomposition of surface litter, composition of microbial community, and soil fertility, as well as physical and chemical properties (Marx et al. 2016; Sterzyńska et al. 2015). In recent years, the investigation of wetland soil fauna has been gradually increasing, concerning the distribution pattern, natural influencing factors, response to environmental pollution and grazing activities, and 
decomposing functions ( $\mathrm{Li}$ et al. 2015; Liu et al. 2016; Wang et al. 2014; Wu et al. 2008; Zhang \& Zhang 2013).

Nanniwan wetland is a swampy wetland on the Loess Plateau, in northern Shaanxi, China. The Great Production Movement (such as land reclamation, and logging and charcoal burning) in the 1950s affected the biodiversity of the Nanniwan wetland (Zhao et al. 2015). These artificial influencing factors changed the Nanniwan wetland into fragmented wetland areas with different degrading degrees. However, there has been few reports concerning the effects of land reclamation on the wetland soil fauna composition (and the related rules and mechanisms), or whether returning farmland could effectively contribute to the wetland restoration.

In this study, the composition, amount, spatial structure, and diversity of the wetland soil fauna in the Nanniwan Wetland Park, as well as the related environmental influencing factors, were investigated in 2016. Model was also established to study the relationship between the soil fauna biomass and environmental factors, to quantitatively predict and evaluate the ecological functions of these soil fauna.

\section{MATERIALS AND METHODS}

\section{TEST-AREA OVERVIEW AND SAMPLE PLOT SELECTION}

The Nanniwan Nature Reserve is located in the southeast of Yan'an, Shaanxi, China, at the altitude of $1230 \mathrm{~m}$, with the catchment area of $3.65 \times 10^{4} \mathrm{hm}^{2}$. It is a hilly and gully region (with $83 \%$ coverage of forest and grass), with the annual average temperature of $8.1{ }^{\circ} \mathrm{C}$ and the annual rainfall of $530-600 \mathrm{~mm}$. In the Nanniwan Nature Reserve, the main woody species included Rosa hugonis, Sophora davidii, Caragana korshinskii, Syringa oblata, Elaeagnus pungens, and Spiraea salicifolia, while the main herbaceous species included Heleocharis dulcis, Typha orientalis, Oenanthejavanica, Helianthus tuberosus, Alisma plantago-aquatica, Phragmites australis, Commelinadiffusa, and Polygonum hydropiper. In this study, based on previously published studies, the surface water status, vegetation characteristics, and main interference patterns were selected as main quantitative indicators (Chen \& Zhang 2012; Liao \& Song 2009). The sample plots in this study were divided into the following six categories: The non-degraded wetland, with constant deep water, about $15-25 \mathrm{~cm}$ in depth, and no interference; the mildly degraded wetland, with seasonal water, about $5-20 \mathrm{~cm}$ in depth, and slight interference from anthropogenic activities; the moderately degraded wetland, with wet surface, generally free of water accumulation, and artificial drainage and grass cutting; the heavily degraded wetland, with no water accumulation, but having waterlogging in sloping fields in strong rainy seasons, and interference of farmland drainage, grass cutting, and burning of wasteland; the reclaimed wetland, which is seasonal marsh wetland before reclaiming, with interference of continuous farming, large quantities of pesticides and chemical fertilizers; and the framingreturning wetland (during recovering process), which is farmland before returning, mainly with no artificial interference. According to the degradation degree and disturbance intensity, the following six sample plots (habitats) were selected in the Nanniwan Nature Reserve (Figure 1): (1) No. 1 plot, severely degraded wetland (109'36'9' E, 36 14 '7' N); (2) No. 2 plot, mildly degraded wetland $\left(109^{\circ} 40^{\prime} 37^{\prime \prime}\right.$ E, 36 $\left.6^{\circ} 18^{\prime} 43^{\prime \prime} \mathrm{N}\right)$; (3) No. 3 plot, non-degraded wetland $\left(109^{\circ} 40^{\prime} 44^{\prime \prime} \mathrm{E}, 36^{\circ} 17^{\prime} 36^{\prime \prime} \mathrm{N}\right)$; (4) No. 4 plot, moderately degraded wetland $\left(109^{\circ} 40^{\prime} 6^{\prime \prime} \mathrm{E}\right.$, $36^{\circ} 19^{\prime} 6$ ' N); (5) No. 5 plot, reclaimed wetland (109 $40^{\prime} 5^{\prime}$ " E,36 $\left.19^{\prime} 6^{\prime \prime} \mathrm{N}\right)$; and (6) No. 6 plot, farmland-returning wetland $\left(109^{\circ} 38^{\prime} 30^{\prime \prime}\right.$ E, $\left.36^{\circ} 17^{\prime} 44^{\prime \prime} \mathrm{N}\right)$. The non-degraded wetland and the reclaimed wetland were used as control.

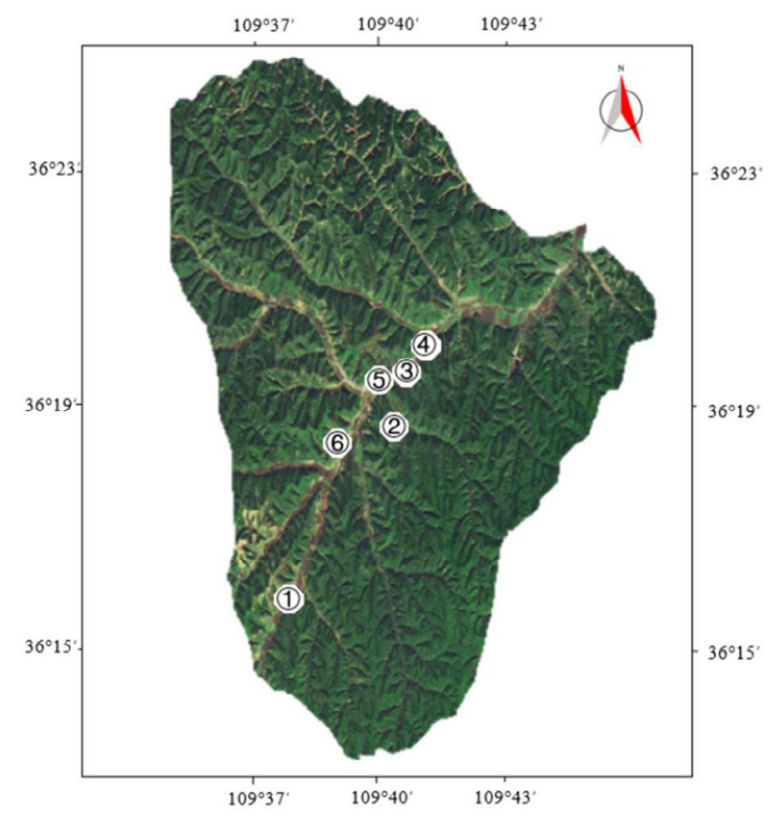

FIGURE 1. Location of Nanniwan wetland and soil fauna sampling plots 


\section{SAMPLE COLLECTION AND IDENTIFICATION}

Totally 72 samples of soil and soil fauna were collected at indicated sampling sites from the habitats in March, June, September, and December, respectively, in 2016. For these 6 different kinds of wetland, sample plots $(10 \times$ $10 \mathrm{~m}$ ) were randomly selected, which were divided into three quadrats. For each quadrat, 3 sampling points were set, i.e., at $0-5 \mathrm{~cm}, 5-10 \mathrm{~cm}, 10-15 \mathrm{~cm}$, and $15-20$ $\mathrm{cm}$ in depth, respectively, with the area of $50 \times 50 \mathrm{~cm}$ for each sampling layer. For the collection of small soil fauna, 100 and $50 \mathrm{~cm}^{3}$ ring knives were used, harvesting 2 soil samples from each soil layer. Soil fauna were isolated with the Tullgren apparatus and Baerman apparatus, which were stored in $75 \%$ ethanol.

The isolated soil fauna was observed and counted with hand-held microscope, and identified and classified according to the Chinese Retrieval of Soil Fauna (Yin 2011). For each soil sample, 0 - 20 mixed samples were subjected to the chemical property analysis, including the contents of total nitrogen (Total N, TN), total organic carbon (TOC), total phosphorus (Total P, TP), total potassium (Total K, TK), and $\mathrm{pH}$. According to the Soil Agrochemical Analysis, TN was analyzed with the Kjeldahl method (LY/T 1228-1999), TOC was determined with the potassium dichromate oxidation and heating method (LY/T 1237-1999), TK was detected with the flame photometry method, and $\mathrm{pH}$ was measured with the acidimeter method (LY/T 1239-1999).

\section{STATISTICAL ANALYSIS}

$\mathrm{R}$ software were used for statistical analysis and figure plotting. The soil animal sizes were determined based on their average width: macrofauna, with the body width of $>$ $2 \mathrm{~mm}$; mesofauna, $2 \mathrm{~mm} \geq$ the body width $\geq 0.2 \mathrm{~mm}$; and microfauna, with the body width $<0.2 \mathrm{~mm}$ (Eileen 2001; $\mathrm{Wu}$ et al. 2006). According to the previously published studies (Cole et al. 2006; Zhang et al. 2001), these soil fauna, were divided into three functional groups according to the ecological functions. Based on the frequency of soil fauna in different sample plots, the soil fauna were categorized as the dominant, common, and rare groups. According to the comment, corresponding changes have been made and corresponding information has been added in the revised manuscript. Dominant, common, and rare groups were defined as densities of $>10 \%, 1 \%-10 \%$, and $<$ $1 \%$, respectively. One-way ANOVA and Duncan multiple comparisons were performed to analyze the effects of habitat types on soil fauna density. Correlation analysis was conducted to calculated the Pearson coefficients for the relationship between the soil fauna density and soil
$\mathrm{pH}, \mathrm{TOC}, \mathrm{TN}, \mathrm{TK}$, and TP. Shannon-Wiener diversity index $\left(H^{\prime}\right)$, Pielou's evenness index $(J)$, and abundance index $(M)$ were calculated for the soil fauna. $P<0.05$ was considered statistically significant.

\section{RESULTS}

\section{SOIL FAUNA COMMUNITY COMPOSITION IN NANNIWAN WETLAND}

A total of 3285 large, medium, and small soil fauna individuals were harvested from the habitats in Nanniwan wetland, belonging to 4 phyla, 10 classes, and 26 orders (Supplementary Table 1). Among these phyla, the dominant phylum was Arthropoda, followed by Nematoda. On the other hand, the dominant species included Acarina (20.27\%), Collembola (14.7\%), and Rhabditida (17.99\%), together accounting for $52.96 \%$ of the total individual numbers. Moreover, there were 13 common species, including Coleoptera, Hymenoptera, Araneae, and Polyxenida, accounting for $43.23 \%$ of the total individual numbers. Furthermore, all the other species accounted for less than $1 \%$ of the total individual numbers, i.e. the rare species.

\section{SOIL FAUNA DENSITY AND DISTRIBUTION IN NANNIWAN WETLAND}

The effects of wetland degradation on the soil fauna density and distribution in Nanniwan wetland were then investigated. Our results showed that the density of large soil fauna ranged from $61.67 \pm 17.26$ to $226.00 \pm 88.32$ ind. $/ \mathrm{m}^{2}$. The large soil fauna density in the non-degraded wetland was significantly higher than the degraded wetland $(\mathrm{F}=6.228 ; P<0.05)$. For the medium soil fauna, the density ranged from $17.00 \pm 1.68$ to $67.00 \pm$ $14.62 \mathrm{ind} . / \mathrm{m}^{2}$. The highest medium soil fauna density was observed in the non-degraded wetland $(\mathrm{F}=15.315$; $P<0.01$ ), while relatively low densities were noted for the severely degraded and reclaimed wetlands. For the small soil fauna, the density ranged from $11.00 \pm 6.92$ to $78.00 \pm 32.08 \mathrm{ind} . / \mathrm{m}^{2}$. The highest density was observed for the non-degraded wetland $(F=9.156 ; P<0.01)$, while relatively low densities were noted for the severely degraded, moderately degraded, reclaimed, and farmlandreturning wetlands. These results suggest that the wetland degradation significantly influences the soil fauna density in Nanniwan wetland.

Moreover, the soil fauna diversities and evenness indexes in these habitats were investigated. As shown in Table 1, the soil fauna diversity index ranked in the following order: non-degraded wetland $>$ severely 
degraded wetland $>$ framing-returning wetland $>$ reclaimed wetland $>$ moderately degraded wetland $>$ mildly degraded wetland. For the soil fauna evenness index analysis: severely degraded wetland $>$ non-degraded wetland $>$ farmreturning wetland $>$ reclaimed wetland $>$ moderately degraded wetland $>$ mildly degraded wetland. Soil fauna evenness index was closely associated with the diversity index. The indexes of diversity and evenness of the mildly degraded wetland and the moderately degraded wetland were significantly lower than those of other plots, and the path analysis results showed that the diversity $\mathrm{H}^{\prime}$ index was positively correlated with the Pielou evenness $J$ index in each plot. For the total soil animal group, the Pielou evenness $J$ index determined the diversity $\mathrm{H}^{\prime}$ index in all these plots. Generally, the soil fauna species were evenly distributed in these habitats, with the highest soil fauna diversity for the non-degraded wetland and the lowest soil fauna diversity for the mildly degraded wetland.

The vertical distribution characteristics of soil fauna were shown in Table 2. Our results showed that surfaceaggregation characteristic was obvious for the vertical distribution of individual and group numbers of soil fauna in Nanniwan wetland. The soil fauna individual and group numbers were gradually decreased along with the increased depth. The largest individual and group numbers were observed for the $0-5 \mathrm{~cm}$ depth soil layer. Moreover, the highest diversity index, evenness index, abundance index, and dominance index were obtained for the 5-10 $\mathrm{cm}$ depth soil layer. In this soil layer, the soil fauna species were abundant, with complex community composition and even distribution.

The percentages of saprozoic soil fauna in the nondegraded wetland was higher than all the other wetlands, and the least in the severely degraded wetland. Predacity soil fauna percentages differed in these wetlands, which were increased along with the degradation severity. The predacity soil fauna percentages were lowest in these wetlands except for the severely degraded wetland. No significant differences were observed in the phytophagous soil fauna among these wetlands, which were the highest within each wetland except for the nondegraded wetland. Except for the reclaimed wetland, significant differences were observed in the percentages of saprozoic soil fauna, phytophagous soil fauna, and predacity soil fauna between these wetlands (Figure 2). These results suggest that the proportions of soil fauna functional groups are significantly changes along with the degradation process of wetland. Generally, wetland degradation and reclamation lead to changed soil fauna functional group, associated with decreased proportion of saprozoic soil fauna and increased proportion of predacity soil fauna.

TABLE 1. Soil fauna biomass and diversity indexes in the Nanniwan wetland

\begin{tabular}{|c|c|c|c|c|c|}
\hline & \multicolumn{3}{|c|}{ Soil fauna density (ind. $/ \mathrm{m}^{2}$ ) } & \multicolumn{2}{|c|}{ Diversity index } \\
\hline & Large soil fauna & Medium soil fauna & Small soil fauna & $\begin{array}{l}\text { Shannon-Wiener } \\
\text { diversity index }\end{array}$ & $\begin{array}{c}\text { Pielou's } \\
\text { diversity index }\end{array}$ \\
\hline $\begin{array}{l}\text { Severely degraded } \\
\text { wetland }\end{array}$ & $71.67 \pm 17.70^{\mathrm{a}}$ & $17.00 \pm 1.68^{\mathrm{a}}$ & $19.33 \pm 5.05^{\mathrm{ab}}$ & $2.465^{\mathrm{a}}$ & $0.810^{\mathrm{a}}$ \\
\hline $\begin{array}{l}\text { Mildly degraded } \\
\text { wetland }\end{array}$ & $105.00 \pm 40.46^{\mathrm{a}}$ & $35.00 \pm 9.13^{\mathrm{bc}}$ & $36.67 \pm 17.02^{b}$ & $2.308^{\mathrm{b}}$ & $0.736^{\mathrm{b}}$ \\
\hline $\begin{array}{l}\text { Non-degraded } \\
\text { wetland }\end{array}$ & $226.00 \pm 88.32^{\mathrm{b}}$ & $67.00 \pm 14.62^{\mathrm{d}}$ & $78.00 \pm 32.08^{c}$ & $2.601^{\mathrm{a}}$ & $0.808^{\mathrm{a}}$ \\
\hline $\begin{array}{l}\text { Moderately } \\
\text { degraded wetland }\end{array}$ & $92.67 \pm 55.95^{\mathrm{a}}$ & $40.00 \pm 1.89^{c}$ & $25.67 \pm 6.38^{\mathrm{ab}}$ & $2.357^{\mathrm{b}}$ & $0.742^{b}$ \\
\hline Reclaimed wetland & $61.67 \pm 17.26^{\mathrm{a}}$ & $23.00 \pm 10.68^{\mathrm{ab}}$ & $11.00 \pm 6.92^{\mathrm{a}}$ & $2.470^{\mathrm{a}}$ & $0.788^{\mathrm{ab}}$ \\
\hline $\begin{array}{l}\text { Farming-returning } \\
\text { wetland }\end{array}$ & $118.00 \pm 16.31^{\mathrm{a}}$ & $45.00 \pm 8.73^{c}$ & $29.67 \pm 4.54^{\mathrm{ab}}$ & $2.538^{\mathrm{a}}$ & $0.788^{\mathrm{ab}}$ \\
\hline
\end{tabular}

Note: Same lowercases at the upper right corner of values indicated no significant difference $(P>0.05)$, and vice versa $(P<0.05)$ 
TABLE 2. Characteristic of soil fauna in different depths in the Nanniwan wetland

\begin{tabular}{cccccc}
\hline $\begin{array}{c}\text { Soil layer } \\
(\mathrm{cm} \text { in depth })\end{array}$ & Group number & $\begin{array}{c}\text { Total number of } \\
\text { individuals }\end{array}$ & Diversity $\left(H^{\prime}\right)$ & Evenness $(J)$ & Abundance $(M)$ \\
\hline $0-5$ & 26 & 1593 & 2.490 & 0.756 & 3.540 \\
$5-10$ & 25 & 962 & 2.533 & 0.777 & 3.664 \\
$10-15$ & 20 & 495 & 2.304 & 0.769 & 3.119 \\
$15-20$ & 18 & 235 & 2.187 & 0.757 & 3.233 \\
\hline
\end{tabular}

\section{RELATIONSHIP BETWEEN SOIL FAUNA DISTRIBUTION AND SOIL PHYSICOCHEMICAL PROPERTIES}

The relationship between the soil fauna distribution and the soil physicochemical properties was next investigated. Our results showed that the habitat $\mathrm{pH}$ values ranged from 8.2 to 8.9 , suggesting meta-alkalescence. Non-degraded wetland had the highest TN. There were significant differences in the TOC, TN, and $\mathrm{pH}$ value between the reclaimed wetland and farm-returning wetland. For the reclaimed and farm-returning wetlands, the TN and TOC contents were significantly lower than the other wetlands (Table 3). These results showed that different habitats have differential soil physicochemical properties.

Correlation analysis showed that soil fauna densities were positively correlated with the soil TOC and TN contents, negatively correlated with the soil $\mathrm{pH}$ values (Figure 3). Moreover, the large, medium, and small soil fauna had differential responses to these three environmental factors. The strongest association with TOC was observed for the small soil fauna $\left(R^{2}=0.4190\right.$ $P=0.005)$, followed by the large soil fauna $\left(R^{2}=0.3022\right.$, $P=0.022)$, and then the medium soil fauna $\left(R^{2}=0.1424\right.$; $P=0.135)$. Moreover, the strongest association with TN was observed for the large soil fauna $\left(R^{2}=0.5119 ; P=\right.$ $0.002)$, followed by the small soil fauna $\left(R^{2}=0.3562 ; P=\right.$ $0.012)$, and then the medium soil fauna $\left(R^{2}=0.1086 ; P=\right.$ 0.197). Furthermore, the strongest association with $\mathrm{pH}$ was observed for the small soil fauna $\left(R^{2}=0.1572 ; P=0.115\right)$, followed by the large soil fauna $\left(R^{2}=0.1490 ; P=0.1552\right)$, and then the medium soil fauna $\left(R^{2}=0.0459 ; P=0.411\right)$.

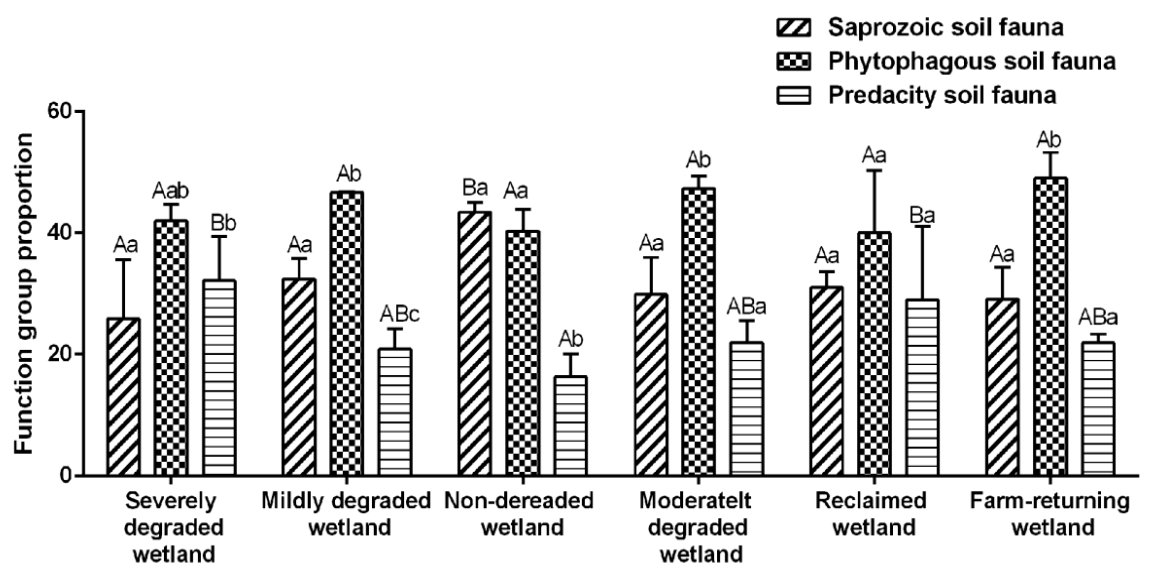

FIGURE 2. Function group dynamics of saprozoic, phytophagous, and predacity soil fauna in different habitats in Nanniwan wetland

Capital letters indicated significant differences between different habitats $(P<0.05)$; lowercase letters indicated significant differences among different functional groups in the same habitat $(P<0.05)$ 
Large soil fauna
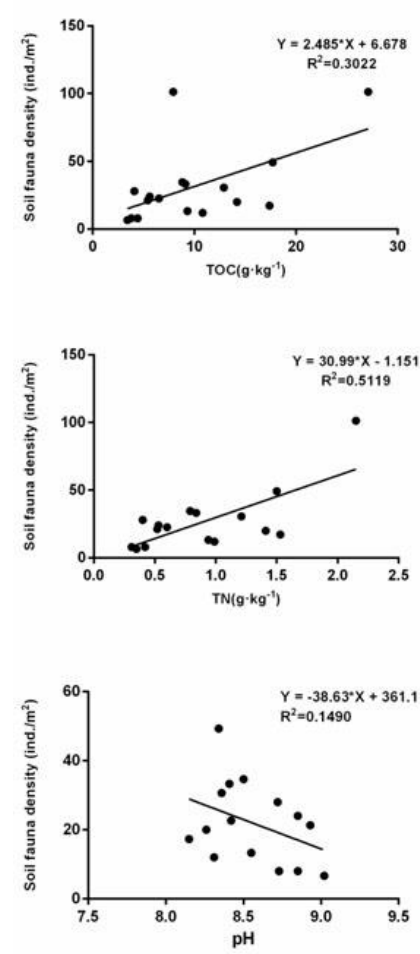

Medium soil fauna
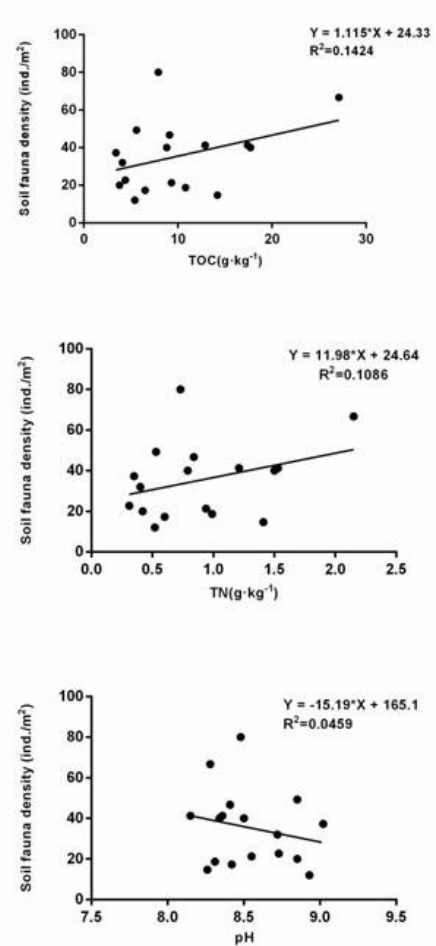

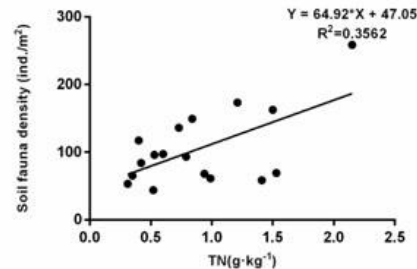

Small soil fauna
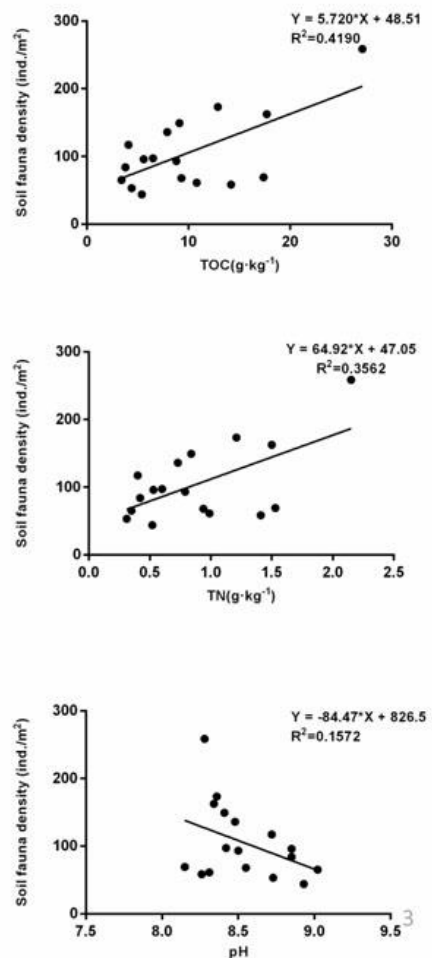

FIGURE 3. Relationships between soil fauna densities and environmental factors

TABLE 3. Soil physicochemical properties in the Nanniwan wetland

\begin{tabular}{|c|c|c|c|c|c|}
\hline & $\mathrm{TN}\left(\mathrm{g} \cdot \mathrm{kg}^{-1}\right)$ & $\mathrm{TP}\left(\mathrm{g} \cdot \mathrm{kg}^{-1}\right)$ & $\mathrm{TK}\left(\mathrm{g} \cdot \mathrm{kg}^{-1}\right)$ & TOC $\left(\mathrm{g} \cdot \mathrm{kg}^{-1}\right)$ & $\mathrm{pH}$ \\
\hline $\begin{array}{l}\text { Severely degraded } \\
\text { wetland }\end{array}$ & $1.33 \pm 0.18^{\mathrm{a}}$ & $0.75 \pm 0.011^{\mathrm{a}}$ & $19.27 \pm 0.27^{\mathrm{a}}$ & $10.50 \pm 2.23^{\mathrm{a}}$ & $8.330 \pm 0.047^{\mathrm{a}}$ \\
\hline Mildly degraded wetland & $1.08 \pm 0.21^{\mathrm{ab}}$ & $0.70 \pm 0.002^{\mathrm{a}}$ & $19.77 \pm 0.03^{\mathrm{a}}$ & $11.93 \pm 2.89^{\mathrm{a}}$ & $8.463 \pm 0.063^{\mathrm{a}}$ \\
\hline Non-degraded wetland & $1.24 \pm 0.45^{\mathrm{ab}}$ & $0.65 \pm 0.002^{\mathrm{a}}$ & $19.46 \pm 0.67^{\mathrm{a}}$ & $14.70 \pm 6.21^{\mathrm{a}}$ & $8.390 \pm 0.059^{\mathrm{a}}$ \\
\hline $\begin{array}{l}\text { Moderately degraded } \\
\text { wetland }\end{array}$ & $1.17 \pm 0.22^{\mathrm{a}}$ & $0.77 \pm 0.009^{\mathrm{a}}$ & $20.60 \pm 0.25^{\mathrm{a}}$ & $12.83 \pm 2.66^{\mathrm{a}}$ & $8.887 \pm 0.084^{\mathrm{a}}$ \\
\hline Reclaimed wetland & $0.36 \pm 0.32^{\mathrm{bc}}$ & $0.57 \pm 0.003^{\mathrm{a}}$ & $18.70 \pm 0.41^{\mathrm{a}}$ & $3.87 \pm 0.29^{\mathrm{b}}$ & $8.833 \pm 0.061^{\mathrm{b}}$ \\
\hline Farm-returning wetland & $0.88 \pm 0.01^{\mathrm{c}}$ & $0.69 \pm 0.020^{\mathrm{a}}$ & $19.61 \pm 0.26^{\mathrm{a}}$ & $5.03 \pm 0.47^{\mathrm{b}}$ & $8.530 \pm 0.060^{\mathrm{b}}$ \\
\hline
\end{tabular}

Note: Same lowercases at the upper right corner of values indicated no significant difference $(P>0.05)$, and vice versa $(P<0.05)$ 


\section{DISCUSSION}

In this study, totally 3285 large, medium, and small soil fauna individuals were harvested from the habitats in Nanniwan wetland, belonging to 4 phyla, 10 classes, and 26 orders. The dominant species included Acarina, Collembola, and Rhabditida. There were 13 common species, including Coleoptera, Hymenoptera, Araneae, and Polyxenida. Moreover, our results showed that the reclamation and degradation of wetland declined the soil fauna density and diversity. Ma et al. (2016) and Ren et al. (2015) have shown that during the wetland degradation process, the plant biomass and diversity are significantly decreased, with large reduction in the underground biomass, suggesting that species replacement occurs along with degradation in the degraded ecosystem of wetland, which might influence the community structure, diversity, and productivity (Wang et al. 2010; Wu \& Yang 2011). Soil fauna have significant adaptability to the long-term global climate change, and the long-term and realistic global changes have less impact on soil biodiversity in the temperate wasteland (Martin et al. 2017).

Soil fauna in Nanniwan wetland exhibited obvious surface aggregation feature, which were decreased along with the increasing depth. Moreover, the temperature, humidity, and surface litter would also affect the spacetime distribution of soil fauna (Sadaka \& Ponge 2003). Generally, wetland degradation and reclamation led to changes in the functional groups of soil fauna, with decreased saprozoic soil fauna and increased predacity soil fauna. The saprozoic and omnivory soil fauna play important roles in the ecological community (Gao et al. 2013). Arthropod species in the soil are mainly saprozoic, while phytophagous and predacity soil arthropod species are rarely seen. Individual numbers of soil fauna could reflect, to a certain extent, the soil quality, and the saprozoic functional groups could serve as potential biological indicators for the function of ecosystem and soil quality (Bardgett et al. 2005; Zhu et al. 2007). The structure and function of the food in soil primarily depends on the main underlying resources, but the functions of the saprozoic and predacity soil fauna should not be ignored (Olena et al. 2017).

The functional groups of soil animals are relatively stable in terms of composition, and individual numbers, which could, to a certain extent, reflect the environmental quality. For the community with superior soil environmental conditions, the proportion of individual populations of sacrificing animals might be relatively higher (Huang \& Zhang 2008). The highest saprozoic soil fauna proportion was observed for the non-degraded wetland, which was lowest for the severely degraded wetland.
This phenomenon might be attributed to the decreased vegetation canopy density during the degradation. Vegetation canopy density could affect the soil bulk density and water content, which have greater impact on saprozoic fauna (Zhou et al. 2017). The proportion of predacity soil fauna was increased along with the degradation severity in various plots, which could be used to reveal the current status of degraded ecological environments. These findings were in line with those from Wang et al. (2012) concerning the functional groups of soil animals in Karst desertification areas. The proportion of phytophagous soil fauna is relatively stable, which is consistent with the findings from Liu et al. (2011). The phytophagous soil fauna represent the primary consumers in the ecological pyramid. During the degradation of the wetland ecological environment, the vegetation is less affected, which is more conducive for the phytophagous soil fauna.

The diversity indexes for the mildly degraded wetland and the moderately degraded wetland were significantly lower than the other plots. The moderately degraded wetland is a turning point in the change of biodiversity, which was the transition zone of the ecosystem (Liao \& Song 2009). During the degradation of wetlands, the physical properties of the soil would change greatly. The soil would become firm, the clay content would decrease, the soil bulk density and soil temperature would increase, the soil porosity would decrease, and the soil moisture content would decrease (Wang 2004). All these factors might affect the survival of soil fauna. The results of the path analysis indicated that, the increase in the diversity of soil animal community in the degraded wetlands might be induced by the Pielou evenness $J$ index in these habitats, which was consistent with the findings from Wang et al. (2010).

In this study, our results showed that higher contents of TOC and TN were associated with higher soil fauna density. These findings were in line with the previous studies from Lu et al. (2015) and Zhang et al. (2017), suggesting that carbon and nitrogen may be related to the animal feeding habits (Ren et al. 2015). However, under the alkaline soil condition, the soil fauna density was negatively correlated with the soil $\mathrm{pH}$ value. Soil in the Hebei Province is weakly alkaline ( $\mathrm{pH} 7.52$ - 8.96), negatively correlated with the soil fauna density; soil in the dish-shaped depression area in the Sanjiang Plain is weakly acidic ( $\mathrm{pH} 5.21$ - 5.72), positively correlated with the soil fauna density; and soil in the Nanniwan wetland was weakly alkaline ( $\mathrm{pH} 8.2$ - 8.9), negatively correlated with the soil fauna density. These findings suggest that the soil $\mathrm{pH}$ values would influence the soil fauna survival and distribution. Land utilization alters the 
biodiversity and soil quality, thus, affecting the function of the ecosystem (Yoseph et al. 2017). During the natural restoration of the abandoned farmland, the composition of the soil fauna would be changed, in accordance with the increased carbon uptake before the underground network tightening (Elly et al. 2017). The degradation and reclamation of Nanniwan wetland lead to changes in the plant productivity. Following the degradation and reclamation of wetland, the soil fauna density would be significantly declined. However, farm-returning might contribute, at least partially, to the restoration of soil fauna diversity of the wetland (Zhao et al. 2014). The conversion of natural forests into farmland leads to a decline in the soil quality and stability, which would be restored by the closure of areas and afforestation on the degraded land (Yoseph et al. 2017).

\section{CONCLUSION}

In conclusion, our results showed that disturbance of different intensities led to differential composition of soil fauna in Nanniwan wetland. Reclaimed wetland was associated with the worst habitat condition, with the simplest soil fauna structure, and the reclamation and degradation declined the soil fauna density and diversity in Nanniwan wetland. Moreover, the wetland degradation and reclamation changed the functional groups of soil fauna, with decreased saprozoic soil fauna and increased predacity soil fauna. Furthermore, soil fauna density and groups had response to the changed environment factors. The soil fauna density was positively correlated with the TOC and TN contents, while negatively correlated with the soil $\mathrm{pH}$ value. Large, medium, and small soil fauna exhibited differential responses to the environmental factors. These findings might contribute to the understanding of soil fauna diversity of the Nanniwan wetland, and provide basic evidence for the soil fauna classification.

\section{ACKNOWLEDGEMENTS}

This work was supported by the 13th Five-year National key Research and Development Project (No. 2016 YFC0501705) and the National Natural Science Foundation of China (No. 32060297, 31370541). All authors declare no financial competing interests. All authors declare no non-financial competing interests.

\section{REFERENCES}

Bardgett, R.D., Bowman, W.D., Kaufmann, R. \& Schmidt, S.K. 2005. A temporal approach to linking aboveground and belowground ecology. Trends in Ecology \& Evolution 20(11): 634-641.
Camplin, R.J., Evans, D. \& Green, I.D. 2016. Soil Fauna and Their Effects on Decomposition within Coniferous and Deciduous Tree Soil Samples. Berlin: Springer. pp. 263-273.

Chen, Y. \& Zhang, M. 2012. The indicators for evaluating wetlands degradation in China. Forest Resources Management 2: $116-120$.

Cole, L., Bradford, M.A. \& Shaw, P.J.A. 2006. The abundance, richness and functional role of soil meso and macrofauna in temperate grassland - a case study. Applied Soil Ecology 33(2): 186-198.

Eileen, J.K. 2001. Tillage systems and soil ecology. Soil \& Tillage Research 61: 61-67.

Elly, M., Emilia, S.H. \& Basten, L.S. 2017. Soil networks become more connected and take up more carbon as nature restoration progresses. Nature Communication 8: 14349.

Gao, L., Hou, J., An, Z., Ma, D. \& Gao, B. 2013. Community structure of large size soil acrofauna in different land use types. Grassland Science 7: 1111-1115.

Huang, L. \& Zhang, X. 2008. Soil animal guilds and ecological distribution in forest ecosystems of the Northern Da Hinggan Mountains. Chinese Journal of Soil Science 39(5): 1017-1022.

Jiang, Y., Wang, B., Niu, X., Dong, Z. \& Wang, P. 2016. Contribution of soil fauna respiration to $\mathrm{CO}_{2}$, flux in subtropical Moso bamboo (Phyllostachys pubescens) forests: A comparison of different soil treatment methods. Environmental Earth Sciences 75(13): 1047.

Li, W., Cui, L., Zhao, X., Zhang, M., Gao, C., Zhang, Y. \& Wang, Y. 2015. Community structure and diversity of soil animals in the Lake Taihu lakeshore wetland. Acta Ecologica Sinica 35(4): 944-955.

Liao, Y. \& Song, C. 2009. Research advances for the degradation of wetland ecosystem. Chinese Journal of Soil Science 40(5): 1199-1203.

Liu, J., Wang, X., Chang, L., Gao, M., Sun, X. \& Wu, D. 2016. Temperature response of local soil springtail Protaphorura bicampata (Gisin, 1956) (Cllembola:onychiuridae) in Sanjiang Plain. Soil and Crop 5(2): 110-114.

Liu, R., Zhao, H. \& Zhao, X. 2011. Changes in functional groups of soil macro-faunal community in degraded sandy grassland under post-grazing natural restoration in Hoqin Sand Land. Ecology and Environmental Sciences 20(12): 1794-1798.

Lu, M., Lv, X. \& Guan, Q. 2015. Distribution and influence factors of earthworms in dish depression of Sanjiang Plain. Wetland Science 13(5): 563-568.

Ma, W., Li, G., Shi, W., Wang, H., Luo, Y., Zhang, L. \& Nie, Z. 2016. Changes of plant biomass and species diversity in degradation process of Gahai wetland in Gansu province. Acta Agrestia Sinica 24(5): 960-966.

Martin, H., Christian, D., Inger, K.S., Arndal, M.F., Beier, C., Mikkelseb, T.N., Ambus, P., Larsen, K.S., Pilegaard, K., Michelsen, A., Andresen, L.C., Haugwitz, M., Bergmark, L., Prieme, A., Zaitsev, A.S., Georgieva, S., Dam, M., Vestergard, M. \& Christensen, S. 2017. Long-term and realistic global change manipulations had low impact on diversity of soil biota in temperate heathland. Scientific Reports 7: 41388. 
Marx, M.T., Yan, X., Wang, X., Song, L., Wang, K., Zhang, B. \& Wu, D. 2016. Soil fauna abundance, feeding and decomposition in different reclaimed and natural sites in the Sanjiang Plain wetland, Northeast China. Wetlands 36(3): 445-455.

Olena, G., Karolin, M., Olaf, B., Andreas, S., Ellen, K., Stefan, S., Kai, U.T. \& Liliane, R. 2017. Disentangling the root- and detritus-based food chain in the micro-food web of an arable soil by plant removal. PLoS ONE 12(7): e0180264.

Ren, G., Deng, B. \& Hou, Y. 2015. Changes of community characteristics in the degradation process of the alpine swamp wetland in the Yellow River source area. Grassland Science 32(8): 1222-1229.

Sadaka, N. \& Ponge, J.F. 2003. Soil animal communities in holm oak forests: Influence of horizon, altitude and year. European Journal of Soil Biology 39(4): 197-207.

Sterzyńska, M., Pižl, V., Tajovský, K., Stelmaszczyk, M. \& Okruszko, T. 2015. Soil fauna of peat-forming wetlands in a natural river floodplain. Wetlands 35(4): 1-15.

Wang, C., Long, R., Wang, Q., Wei, L., Jing, Z. \& Zhang, L. 2010. Fertilization and litter effects on the functional group biomass, species diversity of plants, microbial biomass, and enzyme activity of two alpine meadow communities. Plant and Soil 331(1): 377-389.

Wang, H., Chen, X. \& Yan, C. 2010. Path analysis on diversity indexes of Arthropod community in turf. Resource Development \& Market 26(5): 433-435.

Wang, S. 2004. Analysis on change of physical characteristics of degraded wetland soils in Sanjiang plain. Journal of Soil and Water Conservation 18(3): 167-170.

Wang, X., Chen, H. \& Xiong, K. 2012. Research on the function groups of soil fauna in Karst stone desertification area. Journal of Arid Land Resources and Environment 20(12): 191-195.

Wang, Z., Yin, X. \& Song, X. 2014. Soil fauna community diversity in the swamp of the Longwan National Nature Reserve. Wetland Science 12(5): 566-573.

Whiles, M.R. \& Goldowitz, B.S. 2001. Hydrologic influences on insect emergence production from Central Platte River wetlands. Ecological Applications 11: 1829-1842.

Wu, H.T., Lv, X.G. \& Yang, Q. 2006. Ecological characteristics and functions of soil fauna community. Acta Pedologica Sinica 43(2): 314-323.

Wu, H., Yu, S., Lv, X. \& Jiang, M. 2008. Soil fauna community diversity and litter decomposition in the Carex meyeriana-
Carex lasiocarpa wetland in the Sanjiang Plain. Wetland Science 6(2): 285-292.

Wu, P. \& Yang, D. 2011. Effect of habitat degradation on soil meso- and microfaunal communities in the Zoige Alpine Meadow, Qinghai-Tibetan Plateau. Acta Ecology Sinical 31(13): 3745-3757.

Yin, W. 2011. China Soil Fauna Search Illustration. Beijing: Higher Education Press. pp. 1-691.

Yoseph, T.D., Witoon, P., Amila, B., Birru, Y., Tesfaye, W., Hans, G. \& Douglas, L.G. 2017. Changes in land use alter soil quality and aggregate stability in the highlands of northern Ethiopia. Scientific Reports 7: 13602.

Zhang, W. \& Zhang, X. 2013. Characteristics of soil faunal community structure in mires and wet meadows on different tundras in Da Hinggan Mountains. Wetland Science 11(1): 145-150.

Zhang, X., Hou, W. \& Hou, P. 2001. Soil animal guilds and their ecological distribution in the northeast of China. Chinese Journal of Applied \& Environmental Biology 7(4): 370374.

Zhang, Y., Bi, Y., Li, G. \& Shen, L. 2017. Relationship between earthworm diversity and soil environment in Hebei area. Journal of China Agricultural University 22(3): 60-68.

Zhao, G., Liu, C. \& Wang, W. 2015. On ecological changes of Naniwan Wetland. Wetland Science and Management 11(1) 65-67.

Zhao, G., Liu, J., Kuang, W. \& Ouyang, Z. 2014. Disturbance impacts of land use change on biodiversity conservation priority areas across China during 1990-2010. Acta Geographica Sinica 69(11): 1640-1650.

Zhou, H., Zhang, D. \& Zhang, J. 2017. Effects of canopy density on the functional group of soil macro fauna in Pinus massoniana. Chinese Journal of Applied Ecology 28(6): 1860-1868.

Zhu, X., Gao, B., Bi, H., Wang, W., Yuan, S. \& Hu, Y. 2007. Community diversity of soil arthropods in forest-steppe ecotone. Ying Yong Sheng Tai Xue Bao 18(11): 2567-2572.

College of Life Sciences

Yan'an University

China

*Corresponding author; email: yadxlch@yau.edu.cn

Received: 18 March 2020

Accepted: 3 November 2020 
SUPPLEMENTARY TABLE 1. Soil fauna community composition in the Nanniwan wetland

\begin{tabular}{|c|c|c|c|c|c|c|c|c|c|}
\hline & \multicolumn{6}{|c|}{ Sample plots (individual numbers) } & \multirow{2}{*}{$\begin{array}{l}\text { Total number } \\
\text { of individuals }\end{array}$} & \multirow{2}{*}{ Dominance } & \multirow{2}{*}{ Abundance } \\
\hline & No. 1 & No. 2 & No. 3 & No. 4 & No. 5 & No. 6 & & & \\
\hline Acarina & 48 & 107 & 198 & 116 & 67 & 130 & 666 & 20.27 & +++ \\
\hline Rhabditida & 58 & 110 & 224 & 77 & 33 & 89 & 591 & 17.99 & +++ \\
\hline Collembola & 52 & 96 & 142 & 77 & 35 & 81 & 483 & 14.70 & +++ \\
\hline Coleoptera & 33 & 34 & 64 & 38 & 39 & 46 & 254 & 7.73 & ++ \\
\hline Hymenoptera & 29 & 37 & 57 & 33 & 19 & 35 & 210 & 6.39 & ++ \\
\hline Araneae & 28 & 32 & 48 & 37 & 16 & 43 & 204 & 6.21 & ++ \\
\hline Polyxenida & 10 & 11 & 102 & 19 & 10 & 13 & 165 & 5.02 & ++ \\
\hline Hemiptera & 10 & 21 & 49 & 15 & 18 & 18 & 131 & 3.99 & ++ \\
\hline Lumbricida & 2 & 13 & 32 & 9 & 17 & 24 & 97 & 2.95 & ++ \\
\hline Homoptera & 5 & 16 & 25 & 9 & 4 & 15 & 74 & 2.25 & ++ \\
\hline Isopoda & 8 & 6 & 33 & 5 & 6 & 16 & 74 & 2.25 & ++ \\
\hline Diptera & 5 & 10 & 20 & 6 & 1 & 14 & 56 & 1.70 & ++ \\
\hline Opisthopora & 4 & 8 & 14 & 6 & 4 & 7 & 43 & 1.31 & ++ \\
\hline Coleoptera (larvae) & 6 & 3 & 15 & 4 & 4 & 10 & 42 & 1.28 & ++ \\
\hline Haplotaxide & 5 & 2 & 19 & 7 & 3 & 1 & 37 & 1.13 & ++ \\
\hline Orthoptera & 6 & 9 & 6 & 5 & 2 & 5 & 33 & 1.00 & ++ \\
\hline Aacriformes & 3 & 1 & 10 & 1 & & 4 & 19 & 0.58 & + \\
\hline Scutigeromorpha & 5 & 4 & 7 & 1 & 0 & 2 & 19 & 0.58 & + \\
\hline Diptera (larvae) & 1 & 1 & 8 & 1 & & 6 & 17 & 0.52 & + \\
\hline Stylommatophora & 1 & 2 & & 1 & 2 & 8 & 14 & 0.43 & + \\
\hline Geophilomorpha & 2 & & 2 & 4 & 3 & 2 & 13 & 0.40 & + \\
\hline Lepidoptera (larvae) & & 2 & 3 & 1 & 1 & 4 & 11 & 0.33 & + \\
\hline Basommatophora & & 1 & 7 & & 1 & & 9 & 0.27 & + \\
\hline Pseudoscorpions & & & 5 & 1 & & 2 & 8 & 0.24 & + \\
\hline Hymenoptera (larvae) & & 1 & 1 & & & 3 & 5 & 0.15 & + \\
\hline Euplexoptera & & & 1 & & 3 & & 4 & 0.12 & + \\
\hline Protura & & 1 & 1 & & 1 & & 3 & 0.09 & + \\
\hline Mesogastropoda & & & & & & 2 & 2 & 0.06 & + \\
\hline Lithobiomorpha & & & & 1 & & & 1 & 0.03 & + \\
\hline $\begin{array}{l}\text { Total individual } \\
\text { numbers }\end{array}$ & 321 & 528 & 1093 & 474 & 289 & 580 & 3285 & & \\
\hline
\end{tabular}

Note: +++ , dominant group $(\geq 10 \%) ;++$, common group $(1 \%-10 \%)$; and + , rare group $(<1 \%)$ 